\title{
Gonadotropin-dependent regulation of bovine pituitary adenylate cyclase-activating polypeptide in ovarian follicles prior to ovulation
}

\author{
Khampoune Sayasith, Kristy A Brown and Jean Sirois
}

Centre de recherche en reproduction animale et Département de biomédecine vétérinaire, Faculté de médecine vétérinaire, Université de Montréal, CP 5000, Saint-Hyacinthe, Québec, Canada J2S 7C6

Correspondence should be addressed to K Sayasith; Email: k.sayasith@umontreal.ca

\begin{abstract}
To study the regulation of bovine pituitary adenylate cyclase-activating polypeptide (PACAP) in preovulatory follicles prior to ovulation, PACAP cDNA was isolated by RT-PCR. Its open reading frame (ORF) is composed of 531 bp, and encodes for a 176-amino acid protein that bears $\mathbf{7 6 - 9 0} \%$ identity with other PACAP homologs. Using bovine preovulatory follicles obtained between 0 and $24 \mathrm{~h}$ after human chorionic gonadotropin (hCG) and semiquantitative RT-PCR/Southern blot, we demonstrate that levels of PACAP mRNA were low at $0 \mathrm{~h}$, markedly increased at 6 and $12 \mathrm{~h}(\mathrm{P}<0.05)$, and declined 18 and $24 \mathrm{~h}$ after hCG. Levels of PACAP mRNA were high in the bovine pituitary, testis, intestine and uterus, but moderate to low in other tissues. Analyses performed on isolated preparations of granulosa and theca cells showed a significant increase of PACAP transcripts in both cell types after hCG, whereas primary granulosa cell cultures revealed high levels of PACAP as well as its receptors PAC-1 and VPAC-2 mRNA after forskolin treatment. Overexpression of the catalytic subunit of protein kinase A (PKA) in granulosa cells stimulated, but treatment with $\mathrm{H89}$ or PKA inhibitor protein inhibited PACAP mRNA expression, whereas PACAP overexpression stimulated an increase in abundance of transcripts for PGHS-2, PGES, EP2 receptor, progesterone receptor, and ADAMTS-1, but not for P450-side chain cleavage and P450 aromatase. Thus, this study demonstrates the gonadotropin-dependent regulation of PACAP mRNA in bovine preovulatory follicles, the importance of PKA activation in the expression of PACAP in granulosa cells, and stimulating effect of PACAP on gene expression during the ovulatory process.

Reproduction (2007) 133 441-453
\end{abstract}

\section{Introduction}

Pituitary adenylate cyclase-activating polypeptide (PACAP) is a neuropeptide that was first isolated from the ovine hypothalamus (Miyata et al. 1989). It belongs to the family of the secretin/glucagon/vasoactive intestinal peptide (VIP; Vaudry et al. 2000), and exists in two secreted isoforms, referred to as PACAP-27 and PACAP-38. Both isoforms are generated from tissue-specific proteolytic processing and alternative $\alpha$-amidation of the same 176-amino acid precursor (Vaudry et al. 2000); and share identical N-terminal 27 amino acids of which expression of PACAP-38 predominates in most mammalian tissues (Miyata et al. 1989). To mediate its action, PACAP binds with marked affinity to three distinct $G$ protein-coupled seven transmembrane receptors, referred to as PACAP receptor-1 (PAC-1), VIP/PACAP-1 (VPAC-1) and VPAC-2 (Vaudry et al. 2000). PAC-1 is highly selective for PACAP, and its binding is followed by activation of both adenylate cyclase and phospholipase C (Morrow et al. 1993, Pisegna \& Wank 1993, Spengler et al. 1993). VPAC-1 and VPAC-2 bind equally PACAP and VIP, and are almost exclusively coupled to adenylate cyclase (Spengler et al. 1993, Rawling \& Hezareh 1996, Jaworski \& Proctor 2000). The expression of PACAP and its receptors can be found in many tissues, including hypothalamus, pituitary, testis and ovary (Vaudry et al. 2000), and the role of PACAP in reproduction has been suggested by studies showing its involvement in the synthesis and release of gonadotropins in pituitary cells in vivo and in vitro (Hart etal. 1992, Osuga et al. 1992, Perrin et al. 1993).

Ovulation is a complex process triggered by luteinizing hormone $(\mathrm{LH}) /$ gonadotropin stimulation that ultimately leads to the rupture of follicles and the release of the germ cell. In rodent ovaries, this stimulation may induce the expression and secretion of PACAP, but its role during the ovulatory process is not clearly understood (Gras et al. 1999, Ko et al. 1999). It is suggested 
that PACAP may be involved in modulation of ovarian functions, including steroidogenesis, accumulation of CAMP, production of plasminogen activator, maturation of the oocyte, and survival of granulosa cells (Vaudry et al. 2000). Likewise, mice deficient in PACAP display a reduction of fertility (Shintani et al. 2002). Little is known about the regulation of PACAP in preovulatory follicles of monoovulatory species, and there is no evidence of PACAP-regulated genes involved in the ovulatory process. Thus, the objectives of the study were to characterize the PACAP CDNA and its gonadotropindependent regulation in bovine preovulatory follicles prior to ovulation, and to determine the effect of PACAP on the expression of genes known to be involved in ovulation.

\section{Materials and Methods \\ Cloning of the bovine PACAP cDNA (cDNA)}

To isolate the bovine PACAP cDNA, RT-PCR was performed using total RNA extracts (100 ng) obtained from preovulatory follicles (Sirois 1994), sense (5'-ATG ACC ATG TGT AGC GGA GCG-3') and antisense (5'CTA CAA ATA CGG TAT TCG CCG-3') primers, and a OneStep RT-PCR kit (Qiagen) as directed by the manufacturer. The sense primer was designed from a highly conserved $5^{\prime}$-end region identified after sequence alignments of human (GenBank Accession number: NM_001117), mouse (GenBank Accession number: NM_009625) and rat (GenBank Accession number: NM_016989) homologs, whereas the antisense primer was designed from a $3^{\prime}$-end region of a partial sequence of the bovine PACAP (GenBank accession number: U7889). RT-PCR reactions consisted of 1 cycle of $50{ }^{\circ} \mathrm{C}$ for $30 \mathrm{~min}$ and $95^{\circ} \mathrm{C}$ for $15 \mathrm{~min}$, and 35 cycles of $94{ }^{\circ} \mathrm{C}$ for $30 \mathrm{~s}, 56{ }^{\circ} \mathrm{C}$ for $1 \mathrm{~min}$, and $72{ }^{\circ} \mathrm{C}$ for $1 \mathrm{~min}$. PCR products were subcloned into pGEM-T Easy vector and sequenced (Centre de service de sequençage, Université Laval, Québec, Canada). By this means, the full-length of bovine PACAP CDNA was obtained.

\section{Cloning of VPAC-2 cDNA fragment}

A fragment of bovine VPAC-2 receptor cDNA was isolated by RT-PCR using total RNA extracts (100 ng) obtained from primary granulosa cells $24 \mathrm{~h}$ after forskolin (FSK) treatment, a OneStep RT-PCR kit as directed by the manufacturer, and sense $\left(5^{\prime}-\mathrm{GCC}\right.$ TCT TCA GGA AGC TGC ACT GC- $\left.3^{\prime}\right)$ and antisense ( $5^{\prime}-$ GCA ACA CCA TGT AGT GGA CGC C-3') primers designed from highly conserved regions identified after sequence alignments of human (GenBank Accession numbers: NM_003383) and rat (GenBank Accession numbers: NM_009511) VPAC-2 receptor. Reaction products were subcloned into pGEM-T Easy vector and sequenced.

\section{In vivo model of ovulation}

Holstein heifers of 2-3 years of age exhibiting normal estrous cycles were used as a model of hCG-induced ovulation to study the regulation of PACAP during the ovulatory process in vivo, as previously described (Sirois 1994). Briefly, bovine preovulatory follicles were obtained after induction of luteolysis on day 7 of the estrous cycle, and i.v. administration of an ovulatory dose of hCG (3000 IU) $36 \mathrm{~h}$ after induction of luteolysis. The ovary bearing the preovulatory follicle was isolated by ovariectomy (via colpotomy) from individual heifers at 0 to $26 \mathrm{~h}$ after hCG (Sirois 1994). The interval of time from hCG administration to ovulation is $26-28 \mathrm{~h}$ in this animal model. The preovulatory follicles were dissected from the ovary with a scalpel, and pieces of follicle wall (i.e. theca interna with attached granulosa cells) were prepared and further dissected into isolated preparations of granulosa and theca cells (Sirois 1994). All tissue samples were stored at $70^{\circ} \mathrm{C}$. All animal procedures were approved by the Institutional Animal Care and Use Committee of the Université de Montréal and were consistent with the guidelines of the Canadian Council of Animal Care.

\section{PACAP construct, granulosa cell cultures and DNA transfection}

To produce the PACAP expression construct, full-length PACAP was amplified by RT-PCR using total RNA extracts (100 ng) obtained from preovulatory follicles, sense (5'-GTG AAT TCG CCG CCA CCA TGG CCA TGT GTA GCG GAG CG-3') and anti-sense ( $5^{\prime}$-ACC TCT AGA CTA CAA ATA CGG TAT TCG CCG-3') primers, and a OneStep RT-PCR kit. Reaction products were subcloned into the expression vector pcDNA 3.1(+) (Invitrogen Life Technologies), and sequenced.

Primary cultures of bovine granulosa cells were prepared as previously described (Liu et al. 1999, Sayasith et al. 2004). Briefly, pairs of bovine ovaries bearing a newly formed corpus luteum and a follicle of 8-12 $\mathrm{mm}$ in diameter (dominant follicle of the first wave of the estrous cycle) were obtained from a slaughterhouse. Granulosa cells were isolated from the largest follicle as previously described (Liu et al. 1997), seeded at a density of $2 \times 10^{6}$ in the $100 \mathrm{~mm}$ Petri-dish containing $10 \mathrm{ml}$ of minimal essential medium (MEM; Invitrogen Life Technologies) supplemented with L-glutamine, nonessential amino acids, $2 \%$ fetal bovine serum, insulin $(1 \mu \mathrm{g} / \mathrm{ml})$, transferrin $(5 \mu \mathrm{g} / \mathrm{ml})$, and penicillin (100 units/ml)-streptomycin $(100 \mu \mathrm{g} / \mathrm{ml})$ and incubated at $37{ }^{\circ} \mathrm{C}$ in a humidified atmosphere of $5 \%$ $\mathrm{CO}_{2}$. To study the regulation of PACAP and its receptors, cells were serum-starved overnight in MEM and then incubated in serum-free MEM containing FSK $(10 \mu \mathrm{M})$. After various times of incubation, cells were harvested, and total RNA extracts were isolated. In some 
experiments, granulosa cells were transfected with the vector expressing bovine PACAP, catalytic subunit of PKA (cPKA) or PKA inhibitor (PKI) polypeptide $(4 \mu \mathrm{g} /$ Petri-dish) using LipofectAMINE PLUS (Invitrogen Life Technologies) in accordance with the manufacturer's protocol. CPKA and PKI polypeptide expression vectors, pRSVcPKA $\alpha$ and pRSVPKI respectively, were generously provided by Dr Richard Maurer (Oregon Health Science University, Portland, Oregon, USA). After $3 \mathrm{~h}$ transfection, cells were incubated in serum-free MEM in the absence or presence of FSK $(10 \mu \mathrm{M})$ or PKA inhibitor H89 (Calbiochem, La Jolla, CA, USA) for $24 \mathrm{~h}$, from which total RNA were extracted.

\section{RNA extraction and semiquantitative RT-PCR/ Southern blot}

All tissues were obtained from a slaughterhouse, and total RNA was isolated from bovine preovulatory follicles, granulosa cell cultures and tissues using the TRIzol reagent, and a Kinematica PT 1200C Polytron Homogenizer (Fisher Scientific, Montréal, Canada), according to manufacturer's instructions. Levels of PACAP and glyceraldehyde-3-phosphate dehydrogenase (GAPDH) mRNA were analyzed by semiquantitative RT-PCR/Southern blot using RNA extracts (100 ng), a OneStep RT-PCR kit and sense (5'-ATG ACC ATG TGT AGC GGA GCG-3') and antisense $\left(5^{\prime}\right.$-GCG TCC TTT GTT TTT AAC CC- $\left.3^{\prime}\right)$ primers specific for bovine PACAP, generating a 513-bp DNA fragment, and sense (5'-GTT TCC AGT AGA TTC CAC CC$\left.3^{\prime}\right)$ and antisense (5'-TCC ACC ACC CTG TTG CTG TA-3') primers specific for bovine GAPDH, producing an 850bp DNA fragment. The reaction conditions were one cycle of $50{ }^{\circ} \mathrm{C}$ for $30 \mathrm{~min}$ and $95^{\circ} \mathrm{C}$ for $15 \mathrm{~min}$ followed by 26 cycles for PACAP of $94{ }^{\circ} \mathrm{C}$ for $30 \mathrm{~s}, 53^{\circ} \mathrm{C}$ for $1 \mathrm{~min}$, and $72{ }^{\circ} \mathrm{C}$ for $2 \mathrm{~min}$, or 13 cycles for GAPDH of $94{ }^{\circ} \mathrm{C}$ for $30 \mathrm{~s}, 59^{\circ} \mathrm{C}$ for $1 \mathrm{~min}$, and $72{ }^{\circ} \mathrm{C}$ for $2 \mathrm{~min}$. The number of cycles used was optimized for each gene to fall within the linear range of PCR amplification. PCR products were electrophoresed on $2 \%$ agarose gels, transferred to nylon membrane and hybridized with corresponding ${ }^{32} \mathrm{P}$ labeled PACAP and GAPDH CDNA fragments using QuikHyb hybridization solution (Stratagene, La Jolla, CA, USA). Membranes were exposed to X-OMAT Kodak films with the intensification screen, and signals were quantified by densitometer using the ImageQuant software.

\section{RT-PCR analysis}

The expression of transcripts for prostaglandin (PG) G/H endoperoxide-2 (PGHS-2), PG synthase (PGES), PG E2 receptor (EP2), progesterone receptor (PR), disintegrin and metalloprotease with thrombospondin-like motifs-1 (ADAMTS-1), cytochrome P450-side chain cleavage (P450scc), cytochome P450 aromatase (P450arom),
PAC-1, and VPAC-2 was analyzed by RT-PCR using RNA extracts (100 ng), a OneStep RT-PCR kit (Qiagen) and appropriate primers (see Table 1). RNA extracts were isolated from untransfected and PACAP-transfected granulosa cells cultured in the absence or presence of FSK $(10 \mu \mathrm{M})$ for $24 \mathrm{~h}$. Each reaction was performed at one cycle of $50{ }^{\circ} \mathrm{C}$ for $30 \mathrm{~min}$ and $95^{\circ} \mathrm{C}$ for $15 \mathrm{~min}$ followed by 35 cycles of $94{ }^{\circ} \mathrm{C}$ for $30 \mathrm{~s}, 59^{\circ} \mathrm{C}$ for $1 \mathrm{~min}$, and $72{ }^{\circ} \mathrm{C}$ for $2 \mathrm{~min}$. PCR products were electrophoresed on $2 \%$ Tris-acetate/EDTA-agarose gels, and the intensity of the band was quantified by densitometer using the ImageQuant software.

\section{Statistical analyses}

One-way ANOVA was used to test the effect of time after hCG on levels of PACAP mRNA in samples. PACAP mRNA levels were normalized with the control gene GAPDH prior to analysis. Statistical analyses were performed using JMP software (SAS Institute, Inc., Carry, NC, USA). When ANOVA indicated a significant $F$ value $(P<0.05)$, Dunnett's test was used for multiple comparisons of individual means.

\section{Results}

\section{Cloning of bovine PACAP cDNA}

To clone bovine PACAP cDNA, RT-PCR was performed using RNA extracts isolated from preovulatory follicles obtained $24 \mathrm{~h}$ after hCG treatment (Sirois 1994), and primers designed from the partial bovine PACAP CDNA and a highly conserved $5^{\prime}$-end region identified after sequence alignments of human, mouse and rat homologs.

Table 1 Details of primer sets used in RT-PCR analyses.

\begin{tabular}{|c|c|c|}
\hline Genes & Primer sequences & $\begin{array}{c}\text { PCR } \\
\text { products } \\
\text { (bp) }\end{array}$ \\
\hline PGSH-2 & $\begin{array}{l}\text { 5'-CACAGTGCACTACATACTTACC-3' (sense) } \\
5^{\prime} \text {-GTCTGGAACAACTGCTCATCGC-3 }{ }^{\prime} \text { (antisense) }\end{array}$ & 735 \\
\hline mPGES & 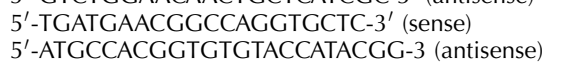 & 330 \\
\hline$E P 2$ & $\begin{array}{l}\text { 5'-CTGCTGGATCATTGGAAGTATGC-3' (sense) } \\
5^{\prime} \text {-TCCATCTCGCTGTTCCACGTG-3' (antisense) }\end{array}$ & 439 \\
\hline$P R$ & 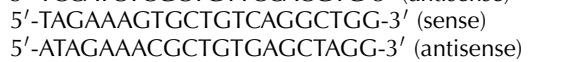 & 742 \\
\hline ADAMTS-1 & $\begin{array}{l}5^{\prime} \text {-GGGACACCGAACAGGAACTGG-3' (sense) } \\
5^{\prime} \text {-GCACTACTACAGGGTGACCAGGGC-3' (antisense) }\end{array}$ & 628 \\
\hline P450scC & 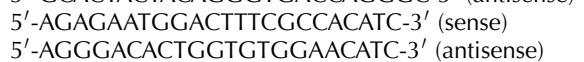 & 525 \\
\hline P450arom & $\begin{array}{l}5^{\prime} \text {-CACATCCTCAATACCAGGTCCC-3' (sense) } \\
5^{\prime} \text {-GGT-GTCCAGCATGATGCG-3' (antisense) }\end{array}$ & 469 \\
\hline$P A C-1$ & $\begin{array}{l}\text { 5'-GTGAGATGGTCCTGGTGAGTTGC-3' (sense) } \\
5^{\prime} \text {-ACCATCCAGCCTTGCATTCC-3' (antisense) }\end{array}$ & 497 \\
\hline VPAC-2 & $\begin{array}{l}\text { 5'-GCCTCTTCAGGAAGCTGCACTGC-3' (sense) } \\
5^{\prime} \text {-GCAACACCATGTAGTGGACGCC-3' (antisense) }\end{array}$ & 589 \\
\hline
\end{tabular}

PGHS-2, prostaglandin G/H synthase-2; mPGES, microsomal prostaglandin E synthase; EP2, prostaglandin E2 receptor; PR, progesterone receptor; ADAMTS-1, a disintegrin and metalloprotease with thrombospondin-like motifs-1; P450scc, cytochrome P450-side chain cleavage; P450arom, cytochrome P450 aromatase; PAC-1, PACAP receptor-1; VPAC-2, vasoactive intestinal peptide/PACAP receptor-2. 
Results showed that the full-length bovine PACAP cDNA consisted of $513 \mathrm{bp}$ (Fig. 1A). Its predicted amino acid sequence encodes a 176-amino acid protein that is the same length as human and sheep, and one amino acid residue longer than mouse, rat, and chicken homologs (Fig. 1B). The nucleotide sequence of bovine PACAP was submitted to GenBank with Accession number AY924308. In comparison to other species, bovine PACAP deduced amino acid sequence is relatively similar to human $(77 \%)$, mouse $(79 \%)$, rat $(76 \%)$, sheep $(90 \%$; GenBank Accession number NM_001009776) and chicken (76\%; GenBank Accession number NM_001001291) homologs, and conserves putative elements for its functions, including the signal peptide, a PACAP-related peptide region, dibasic residues at positions 129-130, 159-160 and 170-171 involved in post-translational peptide cleavage to release PACAP-27 and PACAP-38 isoforms, and an amino acid residue at position 131 required for PACAP activity (Fig. 1B).

\section{Tissue expression of bovine PACAP transcripts and its gonadotropin-dependent regulation in preovulatory follicles}

To investigate the relative expression of PACAP mRNA in various bovine tissues, an RT-PCR/Southern blot was performed, and results showed that levels of the PACAP transcript were high to very high in pituitary, testis, intestine, uterus and preovulatory follicle isolated $12 \mathrm{~h}$ after hCG, and moderate to low or undetectable in other tissues tested (Fig. 2A). In contrast, expression of GAPDH mRNA (control gene) was relatively constant in these tissues (Fig. 2A).

To study the regulation of PACAP mRNA in bovine follicles prior to ovulation, total RNA extracts were prepared from the wall of preovulatory follicles (theca interna with attached granulosa cells) isolated at $0,6,12$, 18 and $24 \mathrm{~h}$ after hCG treatment $(n=4$ distinct follicles (each from a different animal) per time point; except $n=2$ at $6 \mathrm{~h}$ post-h(G). Representative results from RT-PCR/Southern blot revealed that levels of PACAP mRNA were very low or undetectable before the hCG treatment $(0 \mathrm{~h})$, markedly increased at 6 and $12 \mathrm{~h}$, and decreased at 18 and $24 \mathrm{~h}$ post-hCG (Fig. 2B). Results from several follicles expressed as ratios of PACAP to GAPDH indicated that a significant increase in levels of PACAP mRNA was observed from 6 to $18 \mathrm{~h}$ post-hCG as compared to $0 \mathrm{~h}$, with a maximum induction 6 and $12 \mathrm{~h}$ after hCG $(P<0.05$; Fig. 2C).

\section{Cellular localization of PACAP transcripts in preovulatory follicles prior to ovulation}

To determine the cellular localization of bovine PACAP mRNA in preovulatory follicles, RT-PCR/Southern blot was performed using isolated preparations of granulosa and theca cells obtained from preovulatory follicles 0,6 , 12,18 and $24 \mathrm{~h}$ after hCG treatment $(n=2$ distinct follicles (each from a different animal) per time point). In granulosa cells, results showed that the expression of PACAP mRNA was undetectable at $0 \mathrm{~h}$, markedly increased in levels from 6 to $12 \mathrm{~h}$, and decreased between 18 and $24 \mathrm{~h}$ post-hCG (Fig. 3A). When results from several follicles were expressed as PACAP and GAPDH ratios, a significant increase of PACAP transcripts was observed at 6 and $12 \mathrm{~h}$ as compared to $0 \mathrm{~h}$ post-hCG, with a peak at $12 \mathrm{~h}$ post-hCG (Fig. 3B). In theca cells, results revealed that levels of PACAP mRNA were undetectable at $0 \mathrm{~h}$, increased at $6 \mathrm{~h}$, and declined between 12 and $24 \mathrm{~h}$ post-hCG (Fig. 3C). When results from multiple follicles were expressed as PACAP and GAPDH ratios, a marked increase in levels of PACAP mRNA was observed from 6 to $18 \mathrm{~h}$ as compared to $0 \mathrm{~h}$ post-hCG, with a peak at $6 \mathrm{~h}$ post-hCG (Fig. 3D).

\section{PKA pathway-dependent regulation of PACAP transcripts in granulosa cells}

To study the regulation of PACAP mRNA in vitro, granulosa cells were isolated from preovulatory follicles and cultured in the absence or presence of FSK for various times. RT-PCR/Southern blot analyses showed that levels of PACAP mRNA were low at $0 \mathrm{~h}$, markedly increased from 6 to $48 \mathrm{~h}$, with a peak at $12 \mathrm{~h}$ post-FSK (Fig. 4A). When results from three independent experiments were expressed as ratios of PACAP to GAPDH, a significant increase in levels of PACAP mRNA was observed after FSK treatment ( $P<0.05$; Fig. 4B).

To characterize the role of PKA activation in the expression of PACAP mRNA, granulosa cells, either mock transfected or those transfected with the vector expressing CPKA or PKI, were cultured in the absence or presence of FSK and PKA inhibitor H89 for $24 \mathrm{~h}$. RT-PCR analyses showed that levels of PACAP mRNA were low in cells before treatments (control), but greatly increased by FSK or CPKA (Fig. 4C and D, lanes 2 and 5 vs 1), whereas levels of FSK-inducible PACAP mRNA were significantly reduced by $\mathrm{H} 89$ and PKI (Fig. 4C and D, lanes 3 and 4 vs 2 ).

\section{Effect of PACAP overexpression on PGHS-2, PGES, EP2, ADAMTS-1, PR, P450sCC and P450arom mRNA in bovine granulosa cells}

To investigate if PACAP induction may have an effect on the expression of PGHS-2, PGES, EP2, ADAMTS-1, PR, P450scc and P450arom mRNA, granulosa cells, either mock transfected or transfected with the PACAP expression vector, were cultured in the absence or presence of FSK for $24 \mathrm{~h}$. In untransfected cells, results from RT-PCR analyses showed that basal expression of $m$ RNA for PGHS-2, PGES, EP2, ADAMTS-1, PR and P450arom was low or undetectable, but markedly increased by FSK (Fig. 5, lanes 2 vs 1 ). In 
PACAP-transfected cells, overexpression of PACAP stimulated basal expression of mRNA for each gene, except for P450scc and P450arom, initially observed in untransfected cells (Fig. 5, lane 3 vs lane 1), whereas the treatment with FSK enhanced the latter PACAP-dependent stimulation (Fig. 5, lane 4 vs lane 3). In contrast, expression of GAPDH mRNA (control gene) was relatively constant for each samples tested (Fig. 5H).

\section{A}

ATGACCATGTGTAGCGGAGCGAGGC TGGCCCTGCTCGTTTACGGGATACT 50 GATGCACAGCAGCGTCTACGGCTCA CCTGCCGCCTCCGGACTCCGGTTCC 100 CGGGGATCAGGCCGGAGAACGAGGT GTACGACGAGGACGGAAACCCGCAG 150 CAGGACTTCTACGATTCGGAGTCTC TGGGCGTGGGGAGCCCCGCCTCCGC 200 GCTGCGCGATGCCTACGCGCTCTAC TACCCCGCGGAGGAAAGAGATGTCG 250 CCCACGGGATCCTTAATAAGGCCTA CCGCAAAGTGCTGGACCAGCCGTCC 300 GCCAGGAGATCACCTGCAGACGCTC ATGGCCAAGGGCTTGGGTGGGACCC 350 GGGCGGCAGCGCGGACGACGACTCG GAGCCGCTCTCCAAGCGCCACTCGG 400 ACGGCATCTTCACTGACAGCTACAG CCGCTACCGGAAACAAATGGCTGTT 450 AAGAAATACTTGGCTGCTGTTCTAG GGAAAAGGTATAAACAAAGGGTTAA 500 AAACAAAGGACGGCGAATACCGTAT TTGTAG

\section{B}

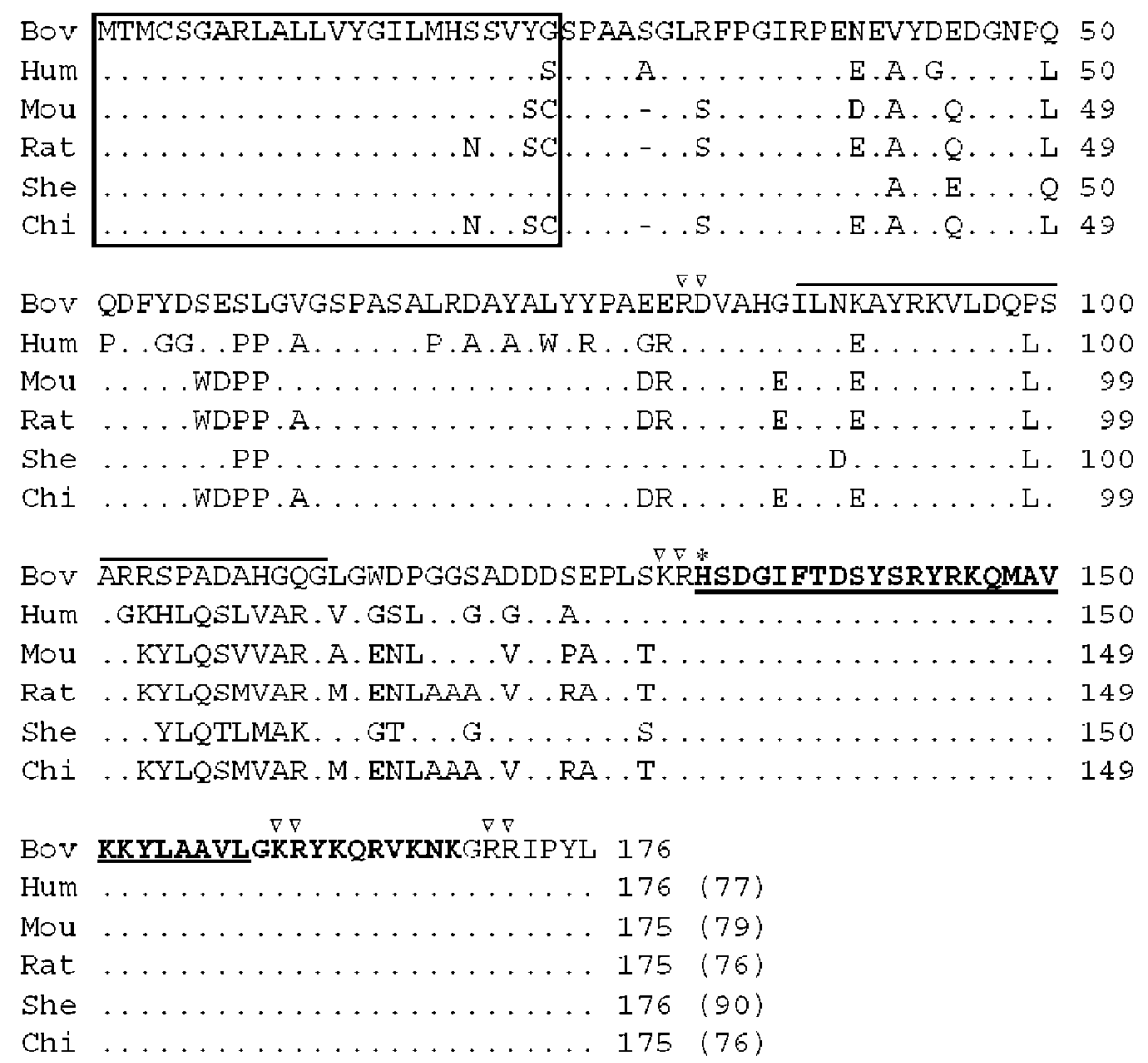

Figure 1 Nucleotide sequence of bovine PACAPand its deduced amino acid sequence in comparison to mammalian homologs. The bovine PACAP CDNA was obtained by the RT-PCR, as described in Materials and Methods. (A) The sequence is composed of an open reading frame of 531 bp. The translation initiation (ATG) and stop (TAG) codons are bolded. Numbers on the right refer to the last nucleotide on that line. (B) The amino acids of bovine PACAP (bov) were deduced from its nucleotide sequence, and aligned with human (hum), mouse (mou), rat, sheep (she) and chicken (chi) homologs. Identical residues are noted by a printed period. Hyphens indicate gaps in protein sequence used to optimize the alignment. The signal peptide is boxed and PACAP-related peptide is overlined. PACAP-38 is bolded and PACAP-27 is underlined. The sites for enzymatic cleavage are indicated by reversed triangles and residue critical for the PACAP activity is marked with an asterisk. Numbers on the right and in parentheses refer to the last amino acid on that line and a degree of identity (percentage) in amino acid residues when comparisons are made with bovine PACAP respectively. 
A

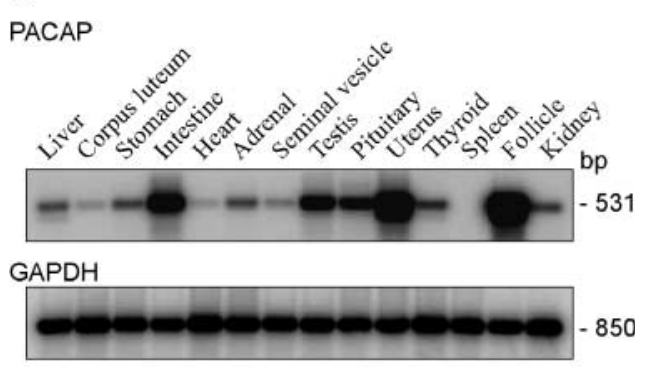

B
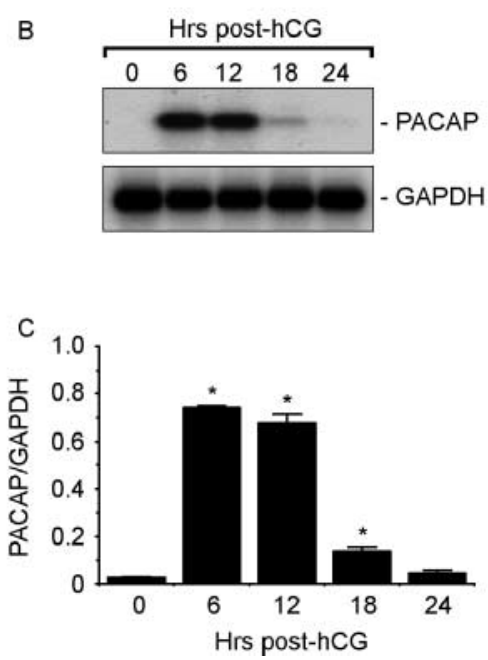

Figure 2 Expression of PACAP mRNA in bovine tissues and its gonadotropin-dependent regulation in preovulatory follicles. (A) Relative expression of bovine PACAP and GAPDH was analyzed by a semiquantitative RT-PCR/Southern blot, as described in Materials and Methods, using total RNA (100 ng) extracted from various bovine tissues. Numbers on the right indicate the size of the PCR fragment. For studies of PACAP mRNA regulation in follicles, RNA extracts were prepared from bovine preovulatory follicles obtained 0, 6, 12, 18 and $24 \mathrm{~h}$ after hCG treatment, and samples (100 ng) were analyzed by a semiquantitative RT-PCR/Southern blot. (B) Representative results of PACAP and GAPDH mRNA levels are presented from one follicle per time point. (D) The PACAP signal was normalized to the corresponding GAPDH level, and results are presented as a ratio of PACAP to GAPDH. Mean \pm S.E.M.; $n=4$ distinct follicles (each from a different animal) per time point; except $n=2$ at $6 \mathrm{~h}$ post-hCG. Bars marked with an asterisk are significantly different from $0 \mathrm{~h}$ post-hCG $(P<0.05)$.

\section{Cloning of the VPAC-2 CDNA and regulation of PAC-1 and VPAC-2 mRNA in granulosa cells}

A fragment of bovine VPAC-2 cDNA was isolated using RNA extracts obtained from granulosa cells $12 \mathrm{~h}$ postFSK, and primers designed from highly conserved regions identified after sequence alignment of human, mouse and rat VPAC-2 homologs. Results from RT-PCR showed that the bovine VPAC-2 DNA fragment of $589 \mathrm{bp}$ was obtained (Fig. 6A), and encodes for a 196 amino acid peptide, corresponding to the human VPAC-2 region of 149-344 amino acid residues. The predicted amino acid sequence of bovine VPAC-2 is highly similar to human $(87 \%)$, rat (84\%) and mouse (85\%) homologs (Fig. 6B).
To examine the regulation of PAC-1 and VPAC-2 in granulosa cells, total RNA extracts isolated from granulosa cells, cultured in the absence or presence of FSK for various times, were analyzed by RT-PCR using pairs of primers specific for bovine PAC-1 (Genbank Accession number: NM_175715) and bovine VPAC-2 fragment obtained from the present study. Results showed that the expression of PAC- 1 mRNA was very low or undetectable at $0 \mathrm{~h}$, markedly increased at 6 and $12 \mathrm{~h}$, and decreased to basal levels at $24 \mathrm{~h}$ post-FSK (Fig. $6 \mathrm{C}$ and D), whereas levels of VPAC-2 mRNA were low at $0 \mathrm{~h}$, highly increased at 6 , and returned to basal levels from 12 to $24 \mathrm{~h}$ post-FSK (Fig. $6 \mathrm{C}$ and E). A fragment of $684 \mathrm{bp}$ for bovine VPAC-1 cDNA was also isolated (data not shown) using RNA extracts from intestine, and primers designed from highly conserved regions identified after sequence alignment of human, mouse and rat VPAC-1 homologs. However, RT-PCR analyses did not reveal the presence of VPAC-1 mRNA expression in bovine granulosa cells (data not shown).

\section{Discussion}

This study is the first to describe the molecular cloning of bovine PACAP CDNA, and the regulation of PACAP as well as its two receptors in bovine preovulatory follicles prior to ovulation. The present study is of interest to assess the importance of PACAP in species with a long ovulatory process, including cows, mares or primates, since there have been no reports on the regulation of PACAP in follicles of large monoovulatory species and previous studies have indicated that several genes, involved in steroidogenesis and ovulation, are differently regulated in preovulatory follicles of these species compared to rodents (Sirois 1994, Duffy \& Stouffer 2001, Joyce et al. 2001, Boerboom et al. 2003). Likewise, the current study identified other key differences. Indeed, the gonadotropin-dependent induction of PACAP transcripts in bovine preovulatory follicles was highly and transiently increased at 6 and $12 \mathrm{~h}$ post-hCG that differs from rodents in which the levels of PACAP were transiently and markedly induced from 3 to $9 \mathrm{~h}$ after hCG in preovulatory follicles, with a maximum induction $6 \mathrm{~h}$ post-hCG (Ko et al. 1999, Lee et al. 1999). Moreover, our data showed that both granulosa and theca cells equally contribute to a high induction of PACAP, differing with its increase in rodents, which is mostly observed in granulosa and cumulus cells of large preovulatory follicles (Gras et al. 1996, Ko et al. 1999, Lee et al. 1999). Taken together, these results suggest that PACAP may have important functions in both follicular cell populations during the ovulatory process. The present study also indicated that high levels of PACAP mRNA were found in the uterus, intestine, pituitary and testis, suggesting that PACAP may play important roles in these tissues. 
A Granulosa

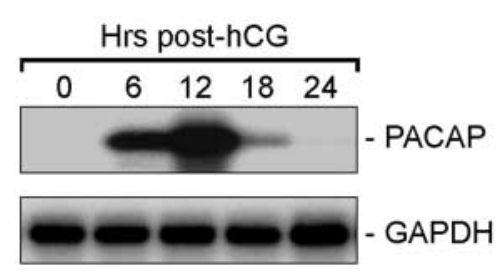

B Granulosa

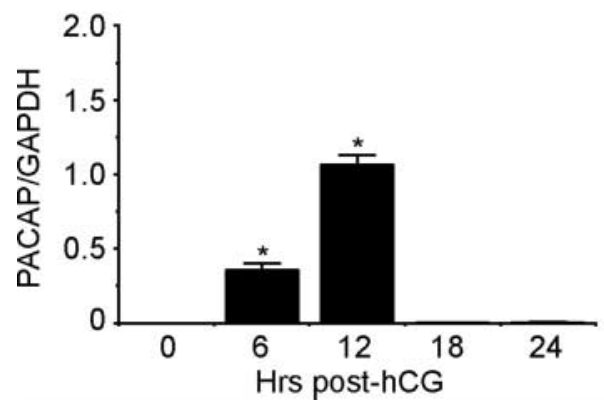

C Theca

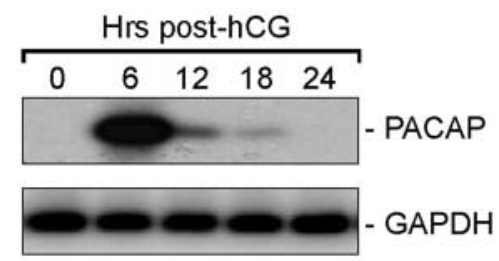

D Theca

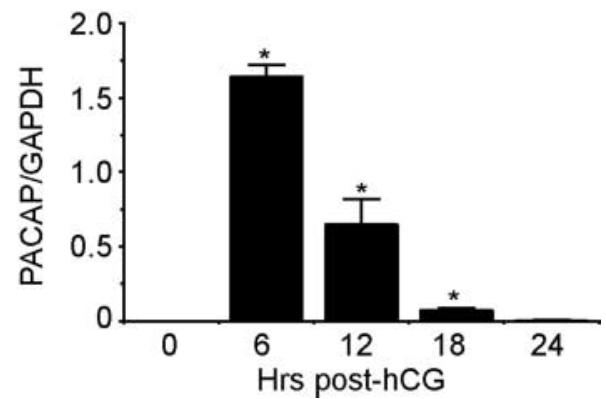

Figure 3 Localization of PACAP mRNA in bovine preovulatory follicles. Bovine preovulatory follicles were isolated from $0,6,12,18$ and $24 \mathrm{~h}$ posthCG. Granulosa and theca cells were prepared from each follicle by the dissection, and used to extract total RNA, as described in Materials and Methods. Samples (100 ng) were analyzed for PACAP and GAPDH mRNA by a semiquantitative RT-PCR/Southern blot. Representative results of PACAP and GAPDH mRNA expression levels are presented from one granulosa (A) and one theca (C) sample per time point. The PACAP signal was normalized to the corresponding GAPDH level, and results are presented as a ratio of PACAP to GAPDH for granulosa (B) and theca (D) cells. $n=2$ distinct follicles (each from a different animal) per time point. Bars marked with an asterisk are significantly different from $0 \mathrm{~h}$ post-hCG $(P<0.05)$.

Ovulation is a complex process triggered by LH surge, during which there is increased expression of several genes thought to be involved in a rupture of the follicle and the release of the oocyte, including PGHS-2, mPGES, membrane type 1-metalloproteinase, early growth factor-1, and PACAP (Richards et al. 2002, Sirois et al. 2004, Sayasith et al. 2006). Many studies have suggested the role of PACAP as a regulator of ovarian functions in the rodent ovary (Lee et al. 1999, Park et al. 2000, Cecconi et al. 2004). Indeed, it has been reported that incubation of preovulatory follicles or granulosa cells with PACAP markedly stimulates cAMP production and amplifies FSH stimulation of CAMP, suggesting that PACAP may act as a mediator for LH during ovulation (Tornell et al. 1988, Heindel et al. 1996, Cecconi et al. 2004). It is known that the preovulatory LH surge induces follicular cAMP production, causing a transient increase of several enzymes and receptors, such as PGHS-2, PR and ADAMTS-1, and production of PGE2 (Richards et al. 2002, Sirois et al. 2004). Furthermore, previous studies have shown that PACAP increases the production of progesterone and PGE2 in the ovary of crested newt, Triturus carnifex (Zhong \& Kasson 1994, Gobbetti et al. 1997, Gras et al. 1999, Ko et al. 1999). In the present work, we used primary granulosa cell cultures that have been previously established as a valuable in vitro model to study the regulation of several bovine genes, including PGHS-2 and CPLA2, and the production of PGE2 recapitulating results observed in vivo (Liu et al. 1999, Sayasith et al. 2004, Diouf et al. 2006). A similar in vitro model was employed in rodents to study the gonadotropin-dependent regulation of PACAP and its role in the suppression of follicle apoptosis (Lee et al. 1999, Park et al. 2000). As the increase in CAMP by LH or FSK leads to the activation of several signaling mechanisms, including PKA and guanine nucleotide-exchange factors (also known as exchange protein directly activated by CAMP or EPAC) signaling pathways (Gonzalez-Robayna et al. 2000, Chin \& Abayasekara 2004, Li et al. 2006), the present study indicates that PKA activation in granulosa cells by FSK changes the expression of PACAP, with a transient increase in the transcript at $12 \mathrm{~h}$ post-hCG as observed in vivo after hCG. Interestingly, we provide new findings to demonstrate that overexpression of PACAP increases the abundance of PGHS-2, mPGES and EP2 mRNA's in bovine granulosa cell cultures, and these responses were amplified by FSK. As the expression of PGHS-2 and EP2 is required for ovulation, our data suggest the involvement of PACAP in ovulatory process with an important role in the prostaglandin biosynthesis pathway, including PGE2 production. In addition, the follicular induction of PGHS-2 (Sirois 1994) and PGES (Filion et al. 2001) occurs much later (18-24 h post-hCG) than that of PACAP (6-12 h post-hCG), thereby supporting the concept that PACAP may be involved in the increase of PGHS-2 and mPGES mRNA in bovine preovulatory follicles. 
It has been reported that $\mathrm{LH} /$ gonadotropin stimulation selectively induces PR, ADAMTS-1 and progesterone production in granulosa cells of preovulatory follicles; and there is evidence to indicate that progesterone,

A
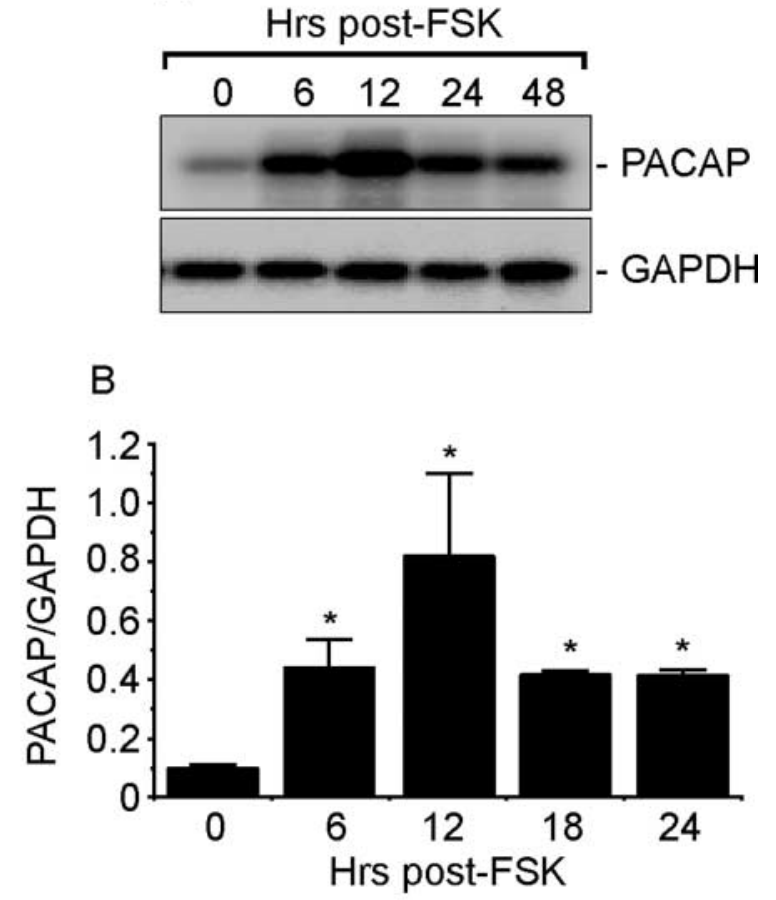

C

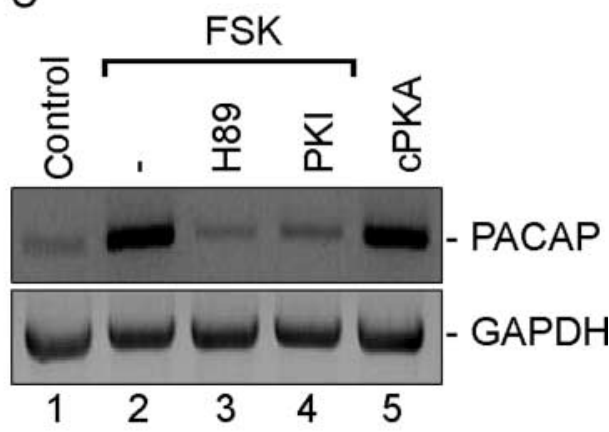

D

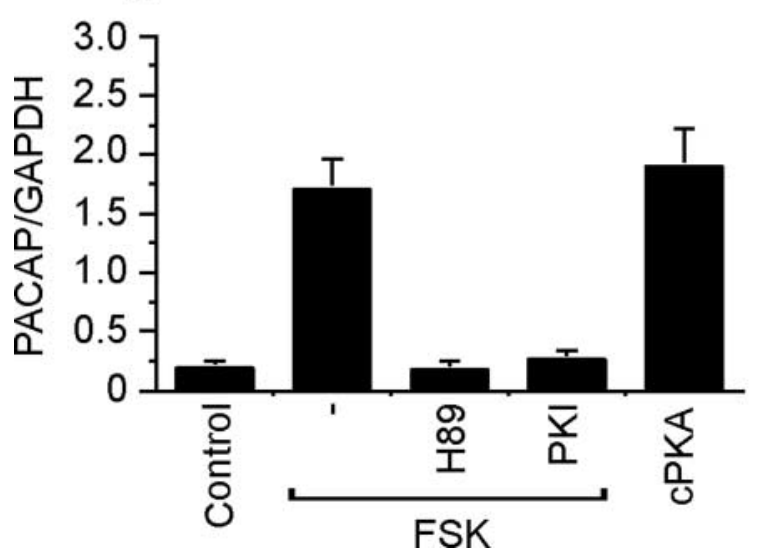

acting through its nuclear receptor (PR), plays an essential role in the regulation of ovulation (Tsafriri et al. 1987, Espey et al. 1990). Furthermore, mice deficient for PR not only fail to undergo the expected induction of ADAMTS-1 but also fail to ovulate (Lydon et al. 1995, Conneely et al. 2000, Robker et al. 2000). Reduction in ADAMTS-1 expression was also observed when the preovulatory synthesis of progesterone was inhibited with epostane (Espey et al. 2000), suggesting that ADAMTS-1 is a downstream target for LH-induced expression of progesterone and PR, and may be involved in proteolytic cascades culminating in the rupture of the follicle. Of note, mice deficient for ADAMTS-1 display impaired ovulation with morphologically abnormal in ovaries (Shindo et al. 2000). The present study reports for the first time that overexpression of PACAP causes a marked increase of PR and ADAMTS- 1 mRNA in granulosa cells. This increase was supported by an induction of PR in granulosa cell cultures after treatment with FSK, in which the levels of PR mRNA were greatly increased from 12 and $24 \mathrm{~h}$ post-FSK (data not shown) as compared to those of PACAP (Fig. 4A and B).

Luteinization is a differentiation process of granulosa cells characterized by a high and constitutive expression of P450scc, changes of transcriptional regulation of PGHS-2 gene from being PKA dependent to PKC dependent, and an increase in cell volume with an appearance of lipid droplets (Morris \& Richards 1995, Wu \& Wiltbank 2002). The present study indicates that expression of several genes was increased in PACAPtransfected cells. As the transfected cells did not display luteinized cell phenotypes, but weakly express P450arom mRNA (a marker of non-luteinized state of granulosa cells), the observed increase in gene expression would appear to be a direct effect of PACAP expression as opposed to a change in differentiation

Figure 4 PKA pathway-dependent regulation of PACAP transcripts in granulosa cells. Primary granulosa cells were isolated from bovine preovulatory follicles, as described in Materials and Methods, and cultured in the presence or absence of forskolin (FSK; $10 \mu \mathrm{M})$ for various times. Total RNA extracts were prepared and used for analyzing the content of PACAP and GAPDH mRNA by a semiquantitative RT-PCR/Southern blot. (A) Representative results of PACAP and GAPDH mRNA signals are presented from one sample per time point. (B) Results are presented as a ratio of PACAP to GAPDH. Mean \pm S.E.M. $(n=3$ independent experiments). Bars marked with an asterisk are significantly different from $0 \mathrm{~h}$ post-FSK $(P<0.05)$. (C) Granulosa cells were cultured in serum-free medium in the absence of forskolin (control) or transiently transfected with the vector expressing catalytic subunit of protein kinase $\mathrm{A}(\mathrm{CPKA})$, or treated with forskolin (FSK, $10 \mu \mathrm{M})$ either alone $(-)$, in the presence of PKA inhibitor $(\mathrm{H} 89,10 \mu \mathrm{M})$ or after transient transfection with the vector expressing the PKA inhibitory polypeptide (PKI). After $24 \mathrm{~h}$ incubation, RNA extracts were prepared and changes in PACAP and GAPDH (internal control) mRNA were analyzed by RT-PCR as described in Materials and Methods. Representative results are presented from one sample per treatment. (D) Results are presented as a ratio of PACAP to GAPDH signal $(n=3$ independent experiments). 


\section{A PGHS-2}

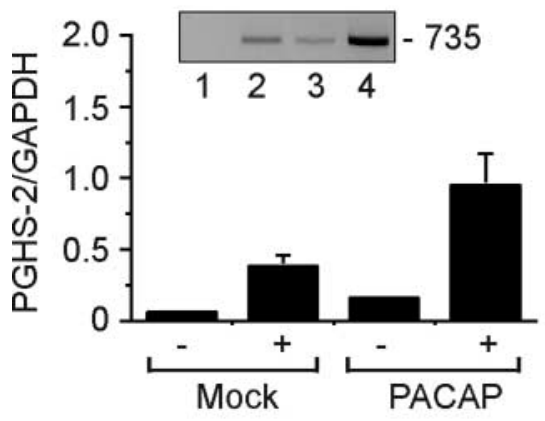

C PR

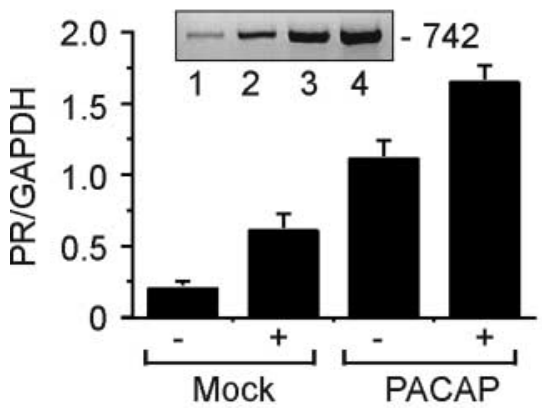

E P450scc

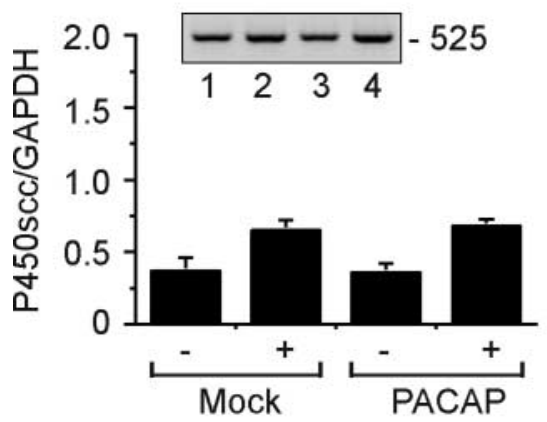

G EP2

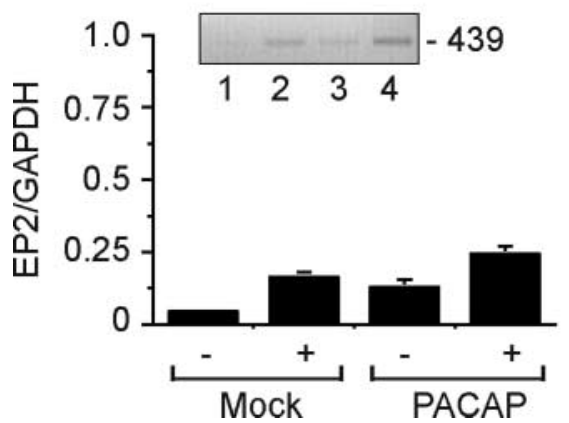

B PGES

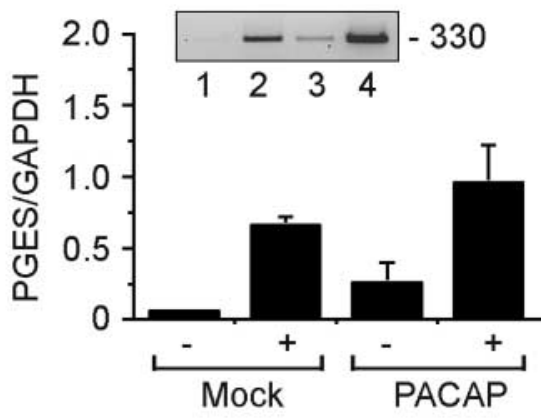

D ADAMTS-1

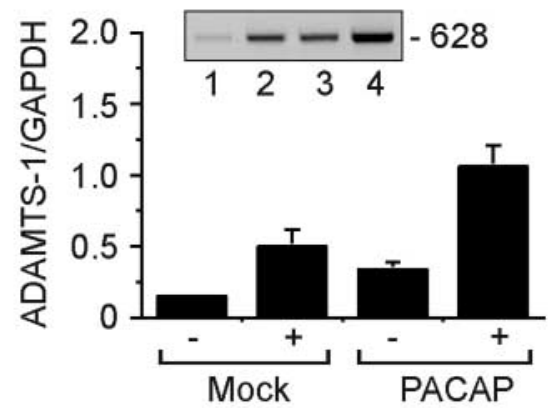

F P450arom

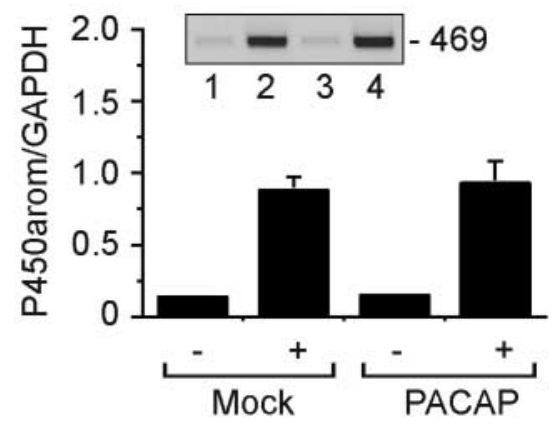

H GAPDH

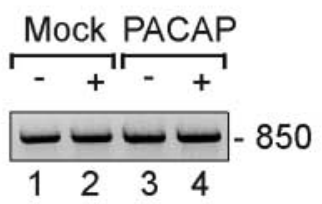

Figure 5 Effect of PACAP overexpression on the expression of PGHS-2, PGES, EP2, ADAMTS-1, P450arom and P450scc transcripts in primary granulosa cells. Granulosa cells, either controls (mock transfected) or those transfected (PACAP) with the vector expressing bovine PACAP, were cultured in the absence $(-)$ or presence $(+)$ of forskolin $(10 \mu \mathrm{M})$ for $24 \mathrm{~h}$. After incubation, RNA extracts were prepared and used (100 ng sample per reaction) to analyze the content of bovine PR, PGHS-2, PGES, EP2, ADAMTS-1, P450scc, P450arom and GAPDH mRNA by RT-PCR reactions, as described in Materials and Methods. Representative results of each gene (A-G; at the top of each panel) and GAPDH (H) mRNA levels are presented from one sample per treatment, and results presented as a ratio of PACAP to GAPDH signal for each treatment $(n=3$ independent experiments) were also depicted. Numbers on the right indicate the size of each PCR fragment in bp. 


\section{A}

TGCCTCTTCAGGAAGCTGCACTGCA CCCGGAACTACATCCACCTGAACCT 50 GTTCTTGTCCTTCATCCTGCGGGCC GTCTCGGTGCTGGTCAAGGACGACG 100 CGCTGTACTCCAGCTCCGGGATGCT GCACTGCCTGGACCTGCCATCCTCC 150 TGGGTGGGCTGCAAGCTGAGCCTGG TCTTCTTCCAGTACTGCATCATGGC 200 CAACTTCTACTGGCTGCTGGTGGAG GGGCTCTACCTCCACACCCTGCTCG 250 CCGTCATCTTCGCCCCCGGCCGGCG CTTCCGGGCCTACCTCCTGATCGGA 300 TGGGGCATCCCCACTGTCTGCACGG GTGCGTGGACTGTGGCTCGGCTCTT 350 GCTGGAGGACACGGGTTGCTGGGAT ACCAATGACCACAGTGTTCCTTGGT 400 GGGTTATACGAACACCAATTTTAAT TTCTATTATAGTCAATTTCATCCTT 450 TTTGTTAGCATTATACGAATTTTAC TGCAGAAGTTGACGCCCCCAGATGT 500 CGGTGGCAACGACCAGTCACAGTAC AAGAGGCTGGCCAAGTCCACCCTGC 550 TGCTCATCCCGCTGTTTGGCGTCCA CTACATGGTGTTGC

\section{B}

BOV CLFRKLHCTRNYIHLNLFLSFILRAVSVLVKDDALYSSSGMLHCLDLPSS 50 Hum $\ldots \ldots \ldots \ldots \ldots \ldots \ldots$. . . . . . . . . . . . . . 50 Rat $\ldots \ldots$.................................. 50 Mou ....................................H.Q.A. 50

BOV WVGCKLSLVFFOYCIMANFYWLLVEGLYLHTLLAVIFAPGRRFRAYLLIG 100 Hum $\ldots \ldots \ldots$. . . . . . F . . . . . . . VAMLP. R.C.L . . . 100 Rat $\ldots \ldots \ldots \ldots \ldots$................................ 100

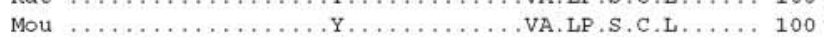
BOV WGIPTVCTGAWTVARLLLEDTGCWDTNDHSVPWWVIRTPILISIIVNFIL 150

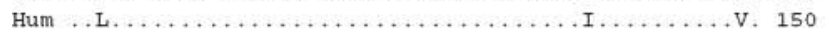
Rat ....S.I...IAT .......................... 150 Mou ....S.I...AT ............................. 150

BOV FVSIIRILLQKLTPPDVGGNDQSQYKRLAKSTLLLIPLFGVHYMVL 196 Hum .I. . . . . . . S . . . . . . . . . . . . . . . . F $196(87 \%)$

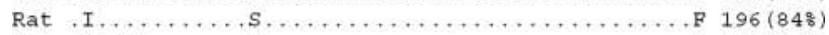
Mou .I..V............................. 196 (85\%)
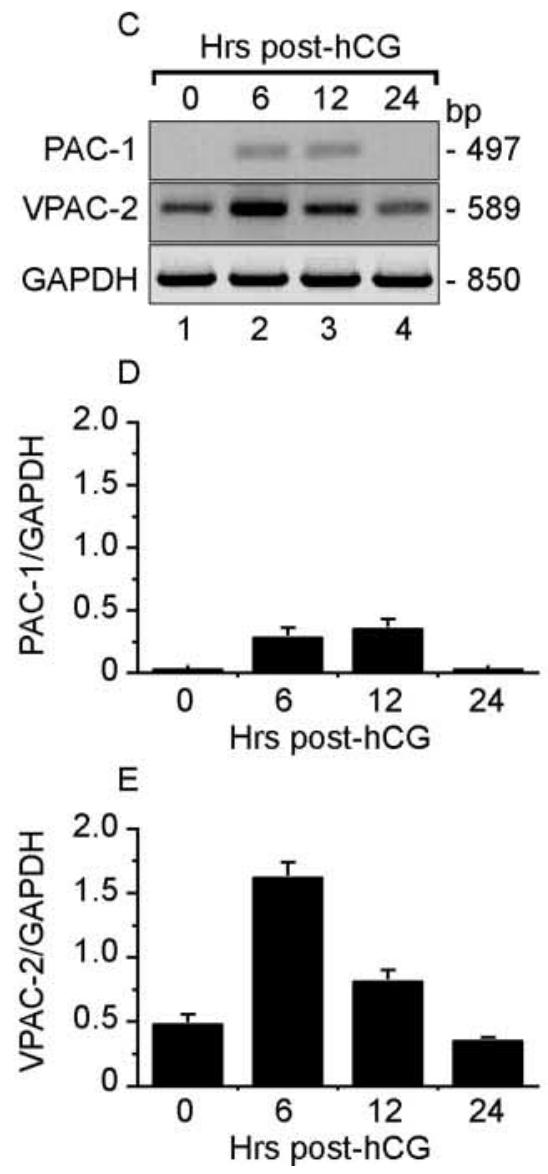

status of the granulosa cells. Further supporting this conclusion, levels of the transcript for P450arom, P450scc and other genes, including PGHS-2, were markedly increased after treatment with FSK (PKA activator), which is also observed in differentiating follicles in vivo and in cultures of non-luteinized granulosa cells isolated from small follicles (Xu et al. 1995, Bao et al. 1997, Sahmi et al. 2004). Additionally, levels of P450arom and P450scc mRNA were not affected by PACAP transfection as compared to untransfected cells. Together, these suggest that granulosa cells were maintained in a non-luteinized state in cultures, and represent a valuable in vitro model to study the regulation of genes involved in the ovulatory process in vivo.

Collectively, our results suggest an important role of PACAP as an autocrine/paracrine regulator in preovulatory follicles. To mediate its biological action, PACAP must be processed and secreted from cells to bind cell surface PACAP receptors. There are at least three types of PACAP receptors, referred to as PAC-1, VPAC-1 and VPAC-2. However, the distribution of PACAP receptor types in the ovary among species is variable. Some reports have suggested that either VPAC- 1 or PAC-1 alone is found in the rat ovary (Gottschall et al. 1990, Scaldaferri et al. 1996), whereas others have indicated that PAC-1 and VPAC-2 mRNA, alone or together, are present in rodent granulosa cells (Gras et al. 2000, Ko \& Park-Sarge 2000, Koh et al. 2000, Park et al. 2000, Apa et al. 2002). Our data indicate that PAC-1 and VPAC-2 were found in bovine granulosa cells and that these are modulated during the ovulatory process. Indeed, treatment with FSK regulated the expression of both receptors in these cells and elevated levels of transcripts for both receptors concurred with an elevated PACAP expression

Figure 6 Partial nucleotide sequence of bovine VPAC-2 cDNA, its deduced amino acid sequence in comparison to other mammalian homologs, and forskolin-dependent regulation of PAC-1 and VPAC-2 transcripts in granulosa cells. (A) The partial sequence of bovine VPAC2 was obtained by the RT-PCR, as described in Materials and Methods, and is composed of an open reading frame of $589 \mathrm{bp}$. Numbers on the right refer to the last nucleotide on that line. (B) The amino acids of bovine VPAC-2 (bov) were deduced from its partial nucleotide sequence; and aligned with human (hum), rat and mouse (mou) homologs. Identical residues are noted by a printed period and numbers in parentheses refer to the degree of identity (percentage) of amino acid residues when comparisons are done with bovine VPAC-2. (C-E) Primary granulosa cells isolated from bovine preovulatory follicles, as described in Materials and Methods, were cultured in serum-free medium in the presence or absence of forskolin for 0 to $24 \mathrm{~h}$. Total RNA extracts were prepared and used to analyze the content of mRNA for PAC-1, VPAC-2 and GAPDH by RT-PCR. (C)

Representative results are presented from one sample per time point. Numbers on the right indicate the size of the PCR fragment in bp. (D and E) The PAC-1 and VPAC-2 signals were normalized to the corresponding GAPDH level respectively; and results are presented as a ratio of PAC- 1 or VPAC-2 to GAPDH. Mean \pm s.E.M.; $n=3$ independent experiments. 
at $6-12 \mathrm{~h}$ post-FSK. However, it is not known whether VPAC-2 or PAC-1 acts alone or together, or to which receptor PACAP binds to exert its biological effects in granulosa cells. More studies are needed for the better understanding of the relative function of the two PACAP receptors.

Information on molecular control of PACAP expression is limited. Previous studies and the present work identified high/ovulatory levels of gonadotropins as a physiological regulator of PACAP in preovulatory follicles (Gras et al. 1996, Lee et al. 1999, Park et al. 2000, 2001). Results from granulosa cell cultures also indicated that the expression of PACAP transcripts is increased by the treatment with LH, FSH, GnRH, FSK and cAMP analogs (Lee et al. 1999, Park et al. 2001, Wang et al. 2003). The present study confirms that the expression of PACAP was significantly stimulated by FSK treatment or CPKA overexpression, but inhibited by PKA inhibitor H89 treatment or PKI overexpression, suggesting that activation of adenylyl cyclase/cAMP/ PKA induces PACAP expression in bovine granulosa cells. In rodents, PR activation is required for PACAP expression in granulosa cells, since treatment with $P R$ antagonist ZK98299 inhibits the effect of hCG on PACAP expression (Ko et al. 1999). Significantly, a potential consensus PR response element has been reported for PACAP promoter (Park et al. 2000), therefore, it will be of interest to understand the importance of the latter element in the regulation of PACAP by PR during the ovulatory process.

In summary, this study is the first to report the molecular cloning of bovine PACAP and describes the induction of PACAP mRNA in the bovine follicle during the ovulatory process. This induction occurred in both granulosa and theca cells after hCG, and a similar induction pattern was obtained in primary granulosa cells cultured with FSK. Moreover, FSK treatment also induced a concomitant increase of PAC- 1 and VPAC-2, as observed with PACAP. Interestingly, overexpression of PACAP in granulosa cells stimulated the transcript expression of genes known to be involved in ovulation, such as PGHS-2, mPGES, EP2, PR and ADAMTS-1, suggesting its potential involvement in the ovulatory process. Further, studies are needed to elucidate the molecular mechanisms of the involvement of PACAP in the regulation of genes implicated in ovulation. As the regulation of these genes occurred in preovulatory follicles can be reproduced in primary granulosa cell cultures, these cultures represent a valuable model to address these issues.

\section{Acknowledgements}

This work was supported by Natural Sciences and Engineering Research Council of Canada Grant OPG0171135 (to J S). The authors declare that there is no conflict of interest that would prejudice the impartiality of this scientific work. The authors would like to thank Drs Bruce Murphy and Alan Goff for review and constructive criticisms of the manuscript, and Dr Richard Maurer (Oregon Health Science University, Portland, Oregon) for his generosity in providing CPKA and PKI polypeptide expression vectors, pRSVCPKA $\alpha$ and pRSVPKI, respectively. The nucleotide sequence reported in this paper has been submitted to the GenBank/EBI Data Bank with Accession numbers AY924308.

\section{References}

Apa R, Lanzone A, Miceli F, Mastrandrea M, Vaccari S, Macchione E, Stefanini M \& Canipari R 2002 Pituitary adenylate cyclase-activating peptide modulates plasminogen activator expression in the rat granulosa cell. Biology of Reproduction 66 830-835.

Bao B, Garverick HA, Smith GW, Smith MF, Salfen BE \& Youngquist RS 1997 Changes in messenger ribonucleic acid encoding luteinizing hormone receptor, cytochrome P450-side chain cleavage, and aromatase are associated with recruitment and selection of bovine ovarian follicles. Biology of Reproduction 56 1158-1168.

Boerboom D, Russell DL, Richards JS \& Sirois J 2003 Regulation of transcripts encoding ADAMTS-1 (a disintegrin and metalloproteinase with thrombospodin-like motifs-1) and progesterone receptor by human chorionic gonadotropin in equine preovulatory follicles. Journal of Molecular Endocrinology 31 473-485.

Cecconi S, Rossi G, Barberi M, Scaldaferri L \& Canipari R 2004 Effect of pituitary adenylate cyclase-activating polypeptide and vasoactive intestinal polypeptide on mouse preantral follicle development in vitro. Endocrinology 145 2071-2079.

Chin EC \& Abayasekara DR 2004 Progesterone secretion by luteinizing human granulosa cels: a possible cAMP-dependent but PKAindependent mechanism involved in regulation. Journal of Endocrinology 183 51-60.

Conneely OM, Lydon JP, De Mayo F \& O'Malley BW 2000 Reproductive functions of the progesterone receptor. Journal of the Society for Gynecologic Investigations 7 S25-S32.

Diouf MN, Sagasith K, Lefebvre R, Silversides DW, Sirois J \& Lussier JG 2006 Expression of phospholipase A2 group IVA (PLA2G4A) is upregulated by human chorionic gonadotropin in bovine granulosa cells of ovulatory cells. Biology of Reproduction 74 1096-1103.

Duffy DM \& Stouffer RL 2001 The ovulatory gonadotropin surge stimulates cyclooxygenase expression and prostaglandin production by the monkey follicle. Molecular Human Reproduction 7 731-739.

Espey LL, Adams RF, Tanaka N \& Okamura H 1990 Effects of epostane on ovarian levels of progesterone, 17 beta-estradiol, prostaglandin E2, and prostaglandin F2 alpha during ovulation in the gonadotropin-primed immature rat. Endocrinology 127 259-263.

Espey LL, Yoshioka S, Russell DL, Robker RL, Fujii S \& Richards JS 2000 Ovarian expression of a disintegrin and metalloproteinase with thrombospondin motifs during ovulation in the gonadotropinprimed immature rat. Biology of Reproduction 62 1090-1095.

Filion F, Bouchard N, Goff AK, Lussier JG \& Sirois J 2001 Molecular cloning and induction of bovine prostaglandin $\mathrm{E}$ synthase by gonadotropins in ovarian follicles prior to ovulation in vivo. Journal of Biological Chemistry 276 34323-34330.

Gobbetti A, Zerani M, Miano A, Bramucci M, Murri O \& Mici D 1997 Presence of pituitary adenylate cyclase-activating polypeptide 38-immuno-like material in the brain and ovary of the female crested newt, Triturus carnifex: its involvement in the ovarian synthesis of prostaglandins and steroids. Journal of Endocrinology 152 141-146.

Gonzalez-Robayna IJ, Falender AE, Ochsner S, Firestone GL \& ichards JS 2000 Follicle-stimulating hormone (FSH) stimulates phosphorylation and activation of protein kinase B (PKB/Akt) and 
serum and glucocorticoid-activation of protein (Sgk): evidence for A kinase-independent signalling by FSH in granulosa cell. Molecular Endocrinology 14 1283-1300.

Gottschall PE, Tatsuno I, Miyata A \& Arimura A 1990 Characterization and distribution of binding sites for the hypothalamic peptide, pituitary adenylate cyclase-activating polypeptide. Endocrinology 127 272-277.

Gras S, Hannibal J, Georg B \& ahrenkrug J 1996 Transient periovulatory expression of pituitary adenylate cyclase activating peptide in rat ovarian cells. Endocrinology 137 4779-4785.

Gras S, Hannibal J \& Fahrenkrug J 1999 Pituitary adenylate cyclaseactivating polypeptide is an auto/paracrine stimulator of acute progesterone accumulation and subsequent luteinization in cultured periovulatory granulosa/lutein cells. Endocrinology 140 2199-2205.

Gras S, Hedetoft C, Pedersen SH \& Fahrenkrug J 2000 Pituitary adenylate cyclase-activating peptide stimulates acute progesterone production in rat granulosa/lutein cells via two receptor subtypes. Biology of Reproduction 63 206-212.

Hart GR, Gowing H \& Burrin JM 1992 Effects of a novel hypothalamic peptide, pituitary adenylate cyclase-activating polypeptide, on pituitary hormone release in rats. Journal of Endocrinology 134 33-41.

Heindel JJ, Sneeden J, Powell CJ, Davis B \& Culler MD 1996 A novel hypothalamic peptide, pituitary adenylate cyclase-activating peptide, regulates the function of rat granulosa cells in vitro. Biology of Reproduction 54 523-530.

Jaworski DM \& Proctor MD 2000 Developmental regulation of pituitary adenylate cyclase-activating polypeptide and PAC(1) receptor mRNA expression in the rat central nervous system. Brain Research and Development 20 27-39.

Joyce IM, Pendola FL, O'Brien M \& Eppig JJ 2001 Regulation of prostaglandin-endoperoxide synthase 2 messenger ribonucleic acid expression in mouse granulosa cells during ovulation. Endocrinology 142 3187-3197.

Ko C \& Park-Sarge OK 2000 Progesterone receptor activation mediates LH-induced type-I pituitary adenylate cyclase activating polypeptide receptor (PAC(1)) gene expression in rat granulosa cells. Biochemical and Biophysical Research Communications 277 270-279.

Ko C, In YH \& Park-Sarge OK 1999 Role of progesterone receptor activation in pituitary adenylate cyclase activating polypeptide gene expression in rat ovary. Endocrinology 140 185-5194.

Koh PO, Kwak SD, Kang SS, Cho GJ, Chun SY, Kwon HB \& Choi WS 2000 Expression of pituitary adenylate cyclase activating polypeptide (PACAP) and PACAP type I A receptor mRNAs in granulosa cells of preovulatory follicles of the rat ovary. Molecular Reproduction and Development 55 379-386.

Lee J, Park HJ, Choi HS, Kwon HB, Arimura A, Lee BJ, Choi WS \& Chun SY 1999 Gonadotropin stimulation of pituitary adenylate cyclase-activating polypeptide (PACAP) messenger ribonucleic acid in the rat ovary and the role of PACAP as a follicle survival factor. Endocrinology 140 818-826.

Li Y, Asuri S, Rebhun JF, Castro AF, Paranavitana NC \& Quilliam LA 2006 The RAP1 guanine nucleotide exchange factor EPAC2 couples cyclic AMP and Ras signals at the plasma membrane. Journal of Biological Chemistry 281 2506-2514.

Liu J, Carriere PD, Dore M \& Sirois J 1997 Prostaglandin G/H synthase2 is expressed in bovine preovulatory follicles after the endogenous surge of luteinizing hormone. Biology of Reproduction $\mathbf{5 7}$ 1524-1531.

Liu J, Antaya M, Boerboom D, Lussier JG, Silversides DW \& Sirois J 1999 The delayed activation of the prostaglandin G/H synthase-2 promoter in bovine granulosa cells is associated with downregulation of truncated upstream stimulatory factor-2. Journal of Biological Chemistry 274 35037-35045.

Lydon JP, DeMayo FJ, Funk CR, Mani SK, Hughes AR, Montgomery CA Jr, Shyamala G, Conneely OM \& O'Malley BW 1995 Mice lacking progesterone receptor exhibit pleiotropic reproductive abnormalities. Genes Development 9 2266-2278.
Miyata A, Arimura A, Dahl RR, Minamino N, Uehara A, Jiang L, Culler MD \& Coy DH 1989 Isolation of a novel 38 residuehypothalamic polypeptide which stimulates adenylate. Biochemical and Biophysical Research Communications 164 567-754.

Morris JK \& Richards JS 1995 Luteinizing hormone induces prostaglandin endoperoxide synthase- 2 and luteinization in vitro by A-kinase and C-kinase pathways. Endocrinology 136 1549-1558.

Morrow JA, Lutz EM, West KM, Fink G \& Harmar AJ 1993 Molecular cloning and expression of a cDNA encoding a receptor for pituitary adenylate cyclase activating polypeptide (PACAP). FEBS Letter 329 99-105.

Osuga Y, Mitsuhashi N \& Mizuno M 1992 In vivo effect of pituitary adenylate cyclase activating polypeptide 38 (PACAP 38) on the secretion of luteinizing hormone (LH) in male rats. Endocrinologia Japonica 39 153-156.

Park HJ, Lee J, Wang L, Park JH, Kwon HB, Arimura A \& Chun SY 2000 Stage-specific expression of pituitary adenylate cyclase-activating polypeptide type I receptor messenger ibonucleic acid during ovarian follicle development in the rat. Endocrinology 141 702-709.

Park JY, Park JH, Park HJ, Lee JY, Lee YI, Lee K \& Chun SY 2001 Stagedependent regulation of ovarian pituitary adenylate cyclaseactivating polypeptide mRNA levels by GnRH in cultured rat granulosa cells. Endocrinology 142 3828-3835.

Perrin D, Soling HD, Wuttke W \& Jarry H 1993 The stimulatory effect of pituitary adenylate cyclase activating polypeptide (PACAP) on LH release from rat pituitary cells in vitro does not involve calcium mobilization. Experimental Clinical Endocrinology 101 290-296.

Pisegna JR \& Wank SA 1993 Molecular cloning and functional expression of the pituitary adenylate cyclase-activating polypeptide type I receptor. PNAS 90 6345-6349.

Rawling S.R. \& Hezareh R. 1996 Pituitary adenylate cyclase-activating polypeptide (PACAP) and PACAP/vasoactive intestinal polypeptide receptors: actions on the anterior pituitary gland. Endocrine Reviews 17 4-29.

Richards JS, Russell DL, Ochsner S \& Espey LL 2002 Ovulation: new dimensions and new regulators of the inflammatory-like response. Annual Review of Physiology 64 69-92.

Robker RL, Russell DL, Espey LL, Lydon JP, O'Malley BW \& Richards JS 2000 Progesterone-regulated genes in the ovulation process: ADAMTS-1 and cathepsin L proteases. PNAS 97 4689-4694.

Sahmi M, Nicola ES, Silva JM \& Price CA 2004 Expression of $17 \beta$ - and $3 \beta$-hydroxysteroid dehydrogenases and steroidogenic acute regulatory protein in non-luteinizing bovine granulosa cells in vitro. Molecular and Cellular Endocrynology 223 43-54.

Sayasith K, Bouchard N, Sawadogo M, Lussier JG \& Sirois J 2004 Molecular characterization and role of bovine upstream stimulatory factor 1 and 2 in the regulation of the prostaglandin G/H synthase- 2 promoter in granulosa cells. Journal of Biological Chemistry $\mathbf{2 7 9}$ 6327-6336.

Sayasith K, Brown AK, Lussier JG, Doré M \& Sirois J 2006 Characterization of bovine early growth response factor- 1 and its gonadotropin-dependent regulation in ovarian follicles prior to ovulation. Journal of Molecular Endocrinology 37 239-250.

Scaldaferri L, Arora K, Lee SH, Catt KJ \& Moretti C 1996 Expression of PACAP and its type-I receptor isoforms in the rat ovary. Molecular Cellular Endocrinology 117 227-232.

Shindo T, Kurihara H, Kuno K, Yokoyama H, Wada T, Kurihara $Y$, Imai T, Wang Y, Ogata M, Nishimatsu $\mathbf{H}$ et al. 2000 ADAMTS-1: a metalloproteinase-disintegrin essential for normal growth, fertility, and organ morphology and function. Journal of Clinical Investigations 105 1345-1352.

Shintani N, Mori W, Hashimoto H, Imai M, Tanaka K, Tomimoto S, Hirose M, Kawaguchi C \& Baba A 2002 Defects in reproductive functions in PACAP-deficient female mice. Regulatory Peptides 109 45-48.

Sirois J 1994 Induction of prostaglandin endoperoxide synthase-2 by human chorionic gonadotropin in bovine preovulatory follicles in vivo. Endocrinology 135 841-848. 
Sirois J, Boerboom D \& Sayasith K 2004 Prostaglandin biosynthesis and action in the ovary. In The Ovary, 2 edn, pp 233-247. Eds PCK Leung \& EY Adashi. Amsterdam: Elsevier academic press.

Spengler D, Waeber C, Pantaloni C, Holsboer F, Bockaert J, Seeburg PH \& Journot L 1993 Differential signal transduction by five splice variants of the PACAP receptor. Nature 365 170-175.

Tornell J, Carlsson B \& Hillensjo T 1988 Vasoactive intestinal peptide stimulates oocyte maturation, steroidogenesis, and cyclic adenosine $3^{\prime}, 5^{\prime}$-monophosphate production in isolated preovulatory rat follicles. Biology of Reproduction 39 213-220.

Tsafriri A, Abisogun AO \& Reich R 1987 Steroids and follicular rupture at ovulation. Journal of Steroid Biochemistry 27 359-363.

Vaudry D, Gonzalez BJ, Basille M, Yon L, Fournier A \& Vaudry H 2000 Pituitary adenylate cyclase-activating polypeptide and its receptors: from structure to functions. Pharmacological Reviews 52 269-324.

Wang Y, Wong AO \& Ge W 2003 Cloning, regulation of messenger ribonucleic acid expression, and function of a new isoform of pituitary adenylate cyclase-activating polypeptide in the zebrafish ovary. Endocrinology 144 4799-4810.
Wu YL \& Wiltbank MC 2002 Transcriptional regulation of the cyclooxygenase-2 gene changes from protein kinase (PK) A- to PKC-dependence after luteinization of granulosa cells. Biology of Reproduction 66 1505-1514.

Xu ZZ, Garverick HA, Smith GW, Smith MF, Hamilton SA \& Youngquist RS 1995 Expression of messenger ribonucleic encoding cytochrome P450-side chain cleavage, cytochrome P45017 $\alpha$ hydroxylase, and cytochrome $\mathrm{P} 450$ aromatase are in bovine follicles during the first wave. Endocrinology 136 981-989.

Zhong Y \& Kasson BG 1994 Pituitary adenylate cyclase-activating polypeptide stimulates steroidogenesis and adenosine $3^{\prime}, 5^{\prime}$-monophosphate accumulation in cultured rat granulosa cells. Endocrinology 135 207-213.

Received 1 September 2006

First decision 16 October 2006

Revised manuscript received 17 November 2006

Accepted 27 November 2006 